\title{
GIS based Mine Spill Damage Assessment
}

\author{
Hyunbock Lee, Huiuk Yi, Youngwook Cheong \\ Korea Institute Geoscience and Mineral Resources (KIGAM) \\ 124 Gwahang-no, Yuseong-gu, Daejeon 305-325, South Korea \\ hblee@kigam.re.kr; yihuiuk@kigam.re.kr; ywc@kigam.re.kr
}

\section{Extended Abstract}

Many studies have been conducted on the mine plug as one of the measures to deal with AMD (acid mine drainage) from abandoned mine sites, and there are many cases where AMD has been treated using the method. ([1], [3], [5], [6]). But there are cases of contamination around closed mines due to mine plug collapses like the Gold King mine blowout in Colorado, USA ([7], [8]). This point has a great influence on the Korean mine reclamation business to control AMD from abandoned mine using mine plugs recently, because the way to estimate the damage of mine blowout have not yet been established.

There are some studies that estimate soil erosion and sediment yield from mine tailing dumps at abandoned mining areas using the GIS in the Korean mine reclamation business ([9], [11]). However, if a massive mine water spill accident occurs such as the Gold-King accident, the method has a limitation in applying the case. So, it is necessary to investigate studies that estimate the damage of flood using GIS. The Ministry of Construction of Japan developed FLEM (Flood Loss Estimation Modelling approach), and US Army Corps of Engineers developed HEC-FDA to estimate flood damage ([4], [10]). And BTRE(Benefits of flood mitigation in Australia) takes into account the damage to residential, commercial, industrial, socioeconomic activities, land and non-structures using the concept of the relationship between the flood depth and the flood damage[2].

Therefore, this study attempts to estimate the potential damage by assuming the accident of mine plug collapse at the Waryong-Joungwon mine in which the mine plug method is considered one of the methods to control AMD with the way of estimation flood damage using GIS.

Because of abnormal rainfall, this study estimate the damage following assumptions

Assumption 1. The mine plug is collapsed due to the increase of the water pressure as result of the full of mine water in the new 1 drift.

Assumption 2. The mine plug is collapsed due to the increase of the water pressure as result of the filling of the mine water in entire drifts (new 1drift, 5 drift, 3 drift, and 1drift).

As in the case of the assumption 1, the volume of the mine water flowing out is theoretically estimated to be $4,435.31$ metric tons, which is the same as the volume of the new 1 drift. In the case of the assumption 2 , the discharge amount is estimated to be 7244.38 metric tons, which is the sum of all drift volumes. And based on the differences in mine drainage runoff estimates from the assumption 1 and the assumption 2, the extent of damage areas are $209,200 \mathrm{~m}^{2}$ and $217,000 \mathrm{~m}^{2}$ respectively. Although the difference in the extent of damage between the assumption 1 and the assumption 2 is not large, it is estimated that the depth of damaged area in the assumption 2 is deeper. The farmland, which is a private property to be compensated for damages, is $161,800 \mathrm{~m}^{2}$ in both the damaged area.

Since the damage compensation by MIRECO (Mining Reclamation Corp.), a Korean government agency, differs by crop type, it must be classified within the extent of damage estimated by GIS. Most of the affected areas are paddy fields, so the compensation for rice is applied as agricultural land compensation. Thus, the estimated damages are about $\$ 144$ million USD for farmland and about \$524 million USD for soil improvement as following.

The estimated results show that there are costs to consider in addition to construction and maintenance costs to select a method to control mine drainage in the study area. 


\section{References}

[1] B. Lang, "Permanent sealing of tunnels to retain tailings or acid rock drainage," in Proceedings of the IEEE International Conference on Image Processing, Austin, TX, vol. 3, pp. 771-775, 1994.

[2] BTRE, Benefits of flood mitigation in Australia. Bureau of Transport and Regional Economics Report 106, 2002.

[3] D. A. Dixon, "Plugs for deposition tunnels in a deep geologic repository in granitic rock," Swedish Nuclear Fuel and Waste Management Co., 2009.

[4] D. Dutta, and S. Herath, "Methodology for Flood Damage Assessment using GIS and Distributed Hydrologic Model," Proceedings of International Symposium on Information Technology Tools for Natural Disaster Risk Management, Bangkok, Thailand, pp. 109-124, 1998.

[5] G. P. Daw and C. A. Pollard, "Grouting for ground water control in underground mining," International Journal of Mine Water, vol. 5, no. 4, pp. 1-40, 1986.

[6] G. S. Littlejohn and A. H. Swart, "Design of permanent intruded plugs at South Deep Gold Mine," J. of The South African Institute of Mining and Metallurgy, vol. 106, pp. 331-342, 2006.

[7] K. Chief, F. Artiola, T. Wilkinson, P. Beamer, and R. M. Maier, "Understanding the Gold King Mine Spill," Superfund Research Program, 2015.

[8] K. Roberts, "A Legacy That No One Can Afford to Inherit: The Gold King Disaster and the Threat of Abandoned Hardrock Legacy Mines,” Journal of the National Association of Administrative Law Judiciary, vol. 36, no. 1, pp. 362-407, 2016.

[9] S. M. Kim, Y. Choi, J. Suha, S. Oha, H. D. Park, S. H. Yoon, "Estimation of soil erosion and sediment yield from mine tailing dumps using GIS: a case study at the Samgwang mine, Korea," Geosystem Engineering, vol. 15, no. 1, pp. 2-9, 2012.

[10] USACE, HEC-FDA: Flood Damage Analysis User's Manual.1998.

[11] W. Song, S. Heo, and T. Kim, "Hydraulic Analysis of Tailing Dam using GIS," J. of Korean Society for Rock Mechanics, vol. 18, no. 5, pp. 375-385, 2008. 